THE EFFECT OF BEAVER PONDS ON THE NONPOINT SOURCE WATER QUALITY OF A STREAM IN

SOUTHWESTERN WYOMING

T.J. Maret

M. Parker

T.E. Fannin

1987

Journal Article

WWRC - $87-13$

In

Water Research

Volume 21, Number 3

1987

\author{
Timothy J. Maret \\ Michael Parker \\ Timothy E. Fannin \\ Department of Zoology and Physiology \\ University of Wyoming \\ Laramie, Wyoming
}




\title{
THE EFFECT OF BEAVER PONDS ON THE NONPOINT SOURCE WATER QUALITY OF A STREAM IN SOUTHWESTERN WYOMING
}

\author{
Timothy J. Maret, Michael Parker* and Timothy E. Fannin \\ Department of Zoology and Physiology, University of Wyoming, Laramie, WY 82071, U.S.A.
}

(Received September 1985)

\begin{abstract}
Currant Creek, a second order stream in southwestern Wyoming, has three large complexes of beaver ponds midway along its $32 \mathrm{~km}$ length. To determine whether these ponds improve the quality of water flowing through them, during spring and summer of 1984 and 1985 water samples were taken upstream from, within, and downstream from the pond complexes. During periods of high flow (i.e. spring runoff), concentrations of suspended solids (SS), total phosphorus (TP), sodium hydroxide-extractable phosphorus $(\mathrm{NaOH}-\mathrm{P}$, an index of biologically available $\mathrm{P}$ ) and total Kjeldahl nitrogen (TKN) were reduced in water flowing through the beaver ponds. During low flow, beaver ponds had less effect on these parameters. Concentrations of nitrate nitrogen $\left(\mathrm{NO}_{3}-\mathrm{N}\right)$ were reduced during both high and low flows, while concentrations of ortho-phosphate (ortho-P) did not appear to be affected by beaver ponds. Ammonia nitrogen almost always was at the limit of detection. Regression of $\mathrm{NaOH}-\mathrm{P}$ versus [SS plus ortho-P] suggested that the primary source of $\mathrm{NaOH}-\mathrm{P}$ was SS. In general, SS explained a large portion of the variation in TP, TKN, and $\mathrm{NaOH}-\mathrm{P}$, and often ortho-P was significantly correiated to TP. The increase in the concentration of most parameters below the area with dam complexes appears to reflect input from bank and channel erosion, and export of SS, TP, TKN and $\mathrm{NO}_{3}-\mathrm{N}$ from beaver dam complexes was calculated to be less than that from stream sections above or below the dams. Thus the location of dams should be considered before using them to try and improve water quality. The apparent importance of bank and channel erosion as the primary source of nutrients to Currant Creek contrasts with many watersheds in agricultural areas.
\end{abstract}

Key words-phosphorus, bioavailable phosphorus, nitrogen, erosion, nonpoint source pollution, watershed, mitigation

\section{INTRODUCTION}

In the arid west, pollution from nonpoint sources is a major water quality problem. For example, approx. $80 \%$ of all nutrients entering Flaming Gorge Reservoir (SW Wyoming and NE Utah) are estimated to originate from nonpoint sources (Southwestern Wyoming Water Quality Planning Association, 1978). Several studies suggest how processes in riparian zones might be used to mitigate such nonpoint source input. Data of Naiman and Melillo (1984), Francis et al. (1985), Smith (1980), and Munther (1982) indicate that beaver ponds may trap sediments and nutrients, thus preventing transport downstream. Other processes within wetlands and beaver ponds also may contribute to nutrient retention or conversion (Apple, 1985; Roseboom and Russell, 1985; Jacobs and Gilliam, 1983; Brinson et al., 1981). More generally, Lowrance et al. (1984) suggest that biological processes in riparian forests act as nutrient filters to reduce input to adjacent streams.

One long-term goal of our research is to determine whether management of beaver on streams could

*To whom all correspondence should be addressed. reduce nutrient loading to lakes or reservoirs. The research reported here was an initial effort to evaluate the effect of beaver ponds on water quality. Two null hypotheses were posed: (1) water quality is unaffected by beaver ponds; and (2) the location of the beaver ponds along the stream (e.g. headwaters only) does not affect the quality of water exported to receiving waters.

\section{DESCRIPTION OF STUDY AREA}

The study was conducted in southwest Wyoming about $48 \mathrm{~km}$ south-southwest of the city of Rock Springs. Research was performed on Currant Creek, a second order stream flowing into the northeast corner of Flaming Gorge Reservoir (Currant Creek Ranch quadrangle, USGS 1:62,500 map). The stream has a drainage area of approx. $132 \mathrm{~km}^{2}$ and a total length of $32 \mathrm{~km}$. Flow originates at an elevation of $2900 \mathrm{~m}$ and empties into the reservoir at $1830 \mathrm{~m}$.

The study area consisted of a $12.9 \mathrm{~km}$ section of stream. The downstream end of the study area is $3.2 \mathrm{~km}$ upstream from the outlet into Flaming Gorge Reservoir. The valley floor in the study area is about $0.3 \mathrm{~km}$ across, and steep sides rise up to $300 \mathrm{~m}$ above 
the valley bottom over a horizontal distance of about $0.6 \mathrm{~km}$. Within the study area, the stream has a gradient ranging from $<1-3 \%$.

The stream is not continuously gauged. During the study, measured discharge ranged from 1.07 to $0.07 \mathrm{~m}^{3} \mathrm{~s}^{-1}$ and measured velocities varied from undetectable to $1.3 \mathrm{~m} \mathrm{~s}^{-1}$. In the study area, width of the stream is between about 1.5 and $6 \mathrm{~m}$. The maximum depth recorded was $1 \mathrm{~m}$. In faster moving sections the stream bottom is firm with a composition of small cobbles, gravel and fine sediments; in deeper areas with lesser velocity the substrate tends to be soft, fine sediment (Platts et al., 1983). During 1984 the observed ranges for conductivity, total dissolved solids and $\mathrm{pH}$ were respectively 520-920 micromhos $\mathrm{cm}^{-1}$ at $25^{\circ} \mathrm{C}, 368-692 \mathrm{mg} \mathrm{l}^{-1}$, and 7.9-8.6.

There is some beaver activity in the headwater region of the basin, followed by a section of about $14 \mathrm{~km}$, apparently without activity, before the study area is reached. Within the study area three large beaver pond complexes vary in length from 0.3 to $0.6 \mathrm{~km}$. There also are numerous individual beaver ponds scattered along the stream between the pond complexes. Extensive areas of marsh and willow (Salix) thickets accompany the beaver ponds. In addition to ponds and riparian areas, the valley floor is occupied by subirrigated and irrigated hay meadows, and dry areas of sagebrush (Artemisia) and greasewood (Sarcobatus). In the downstream $4.0 \mathrm{~km}$ of the study area there are no beaver ponds and the stream is downcut.

Two differences between the 1984 and 1985 field seasons should be noted. First, there were fewer cattle in the study area during 1985 than during 1984 . Second, 1984 was an exceptionally wet year, both in terms of snow-melt and summer rain, while 1985 was quite dry.

\section{METHODS}

In May 1984, automatic water samplers (ISCO Model 1392) were placed at five sites along the stream. These sites, which we refer to as the unpaired stations, were (upstream to downstream): Station 1: upstream from all beaver ponds. Station 2: $3.3 \mathrm{~km}$ from station $\mathrm{l}$ and within a portion of the creek containing beaver ponds. Station $3: 6.5 \mathrm{~km}$ from station 1 and immediately downstream from a section of stream containing beaver ponds. Station $4: 9.7 \mathrm{~km}$ from station 1 and downstream from a $3.2 \mathrm{~km}$ stretch of stream containing no beaver ponds. Station $5: 10.2 \mathrm{~km}$ from station 1 and directly downstream from several small beaver ponds which washed out at the start of spring runoff, 1984

The automatic water samplers were set to collect $250-500 \mathrm{ml}$ at intervals of $5.5-8.0 \mathrm{~h}$. Approximately every seven days the automatic samplers were serviced and their composite samples removed for analysis. Concurrently, a grab sample was taken and the stream was gauged at each station to provide the data necessary for calculating volume discharge. Preservatives never were used in any samples, but all samples were placed on ice in the dark and analyses began within 1-2 h. Sampling continued through early August 1984. The composite samples were analyzed for the following parameters: suspended solids, nonfilterable residue upon evaporation at $180^{\circ}$ C (U.S. EPA, 1983); tota! phosphorus, persulfate digestion, colorimetric-ascorbic acid
(U.S. EPA, 1983); total Kjeldahl nitrogen, distillation, titrimetric (U.S. EPA. 1983). Analyses made on the grab samples were: ortho-phosphate, direct colorimetric-ascorbic acid (U.S. EPA, 1983); NaOH-extractable phosphorus, $\mathrm{NaOH} / \mathrm{NaCl}$ extraction, colorimetric-ascorbic acid (Messer et al., 1984); nitrate nitrogen, Devarda alloy reductiondistillation and titration (APHA, 1980); ammonia nitrogen, distillation, titrimetric (U.S. EPA, 1983).

In early July 1984 we initiated additional sampling at three pairs of stations, with one pair in each of the three beaver pond complexes. These sites are referred to as the paired stations. One station from each pair was located immediately upstream from the ponds in a complex, while the other was located in the downstream end of the complex. Weekly grab samples were taken at these stations and analyzed for all parameters listed above. The stream was gauged at the locations upstream from the pond complexes. Sampling continued at the paired stations through early October 1984.

We resumed sampling in early April 1985. Grab samples only were taken at all stations and again were analyzed for all parameters listed above. No samples were taken at station 5 , because the ponds immediately upstream had washed out early during spring runoff in 1984. Sampling continued through mid-June, 1985.

Statistical analyses were performed on a microcomputer using the MS-DOS version of the software package Systat (Systat Inc., 1984). Two sample $t$-tests were used to determine if concentrations of various parameters were less at unpaired stations associated with the complexes (2 and 3 ) compared to unpaired stations upstream and several $\mathrm{km}$ downstream $(1,4$, and 5$)$. Differences in concentrations between stations at the paired sites (one station was upstream from ponds, the other was in the downstream end of the complex) were tested using pairwise $t$-tests. Simple or multiple linear regressions were used to test for changes in concentration over distance, and relationships between parameters (e.g. discharge and concentration). A level of significance of $P \leqslant 0.05$ was used for all analyses.

\section{RESULTS}

Data from water samples collected at paired and unpaired stations were analyzed separately from data from unpaired stations. Data from different years also were analyzed separately. Such grouping of data was necessary because of different sampling methods (composite or grab), and because of the markedly different importance of erosional and depositional processes in the two areas.

Also, for both years data were divided into groups representing spring runoff and summer flow. This division was made based on decreased flow. In 1984, sampling at unpaired stations did not begin until well into spring runoff. Samples from three trips (May-June) were from the end of runoff, while samples from eight trips (June-August) were taken during summer flow. All nine trips to the paired stations were made during the summer (July-October). During 1985, sampling at all stations began very early during spring runoff. Samples from eight trips (April-May) were from spring runoff, while four trips were made during the summer (May-June). Average concentrations of the chemical parameters during both runoff and summer flow of the two years are illustrated in Fig. 1. 

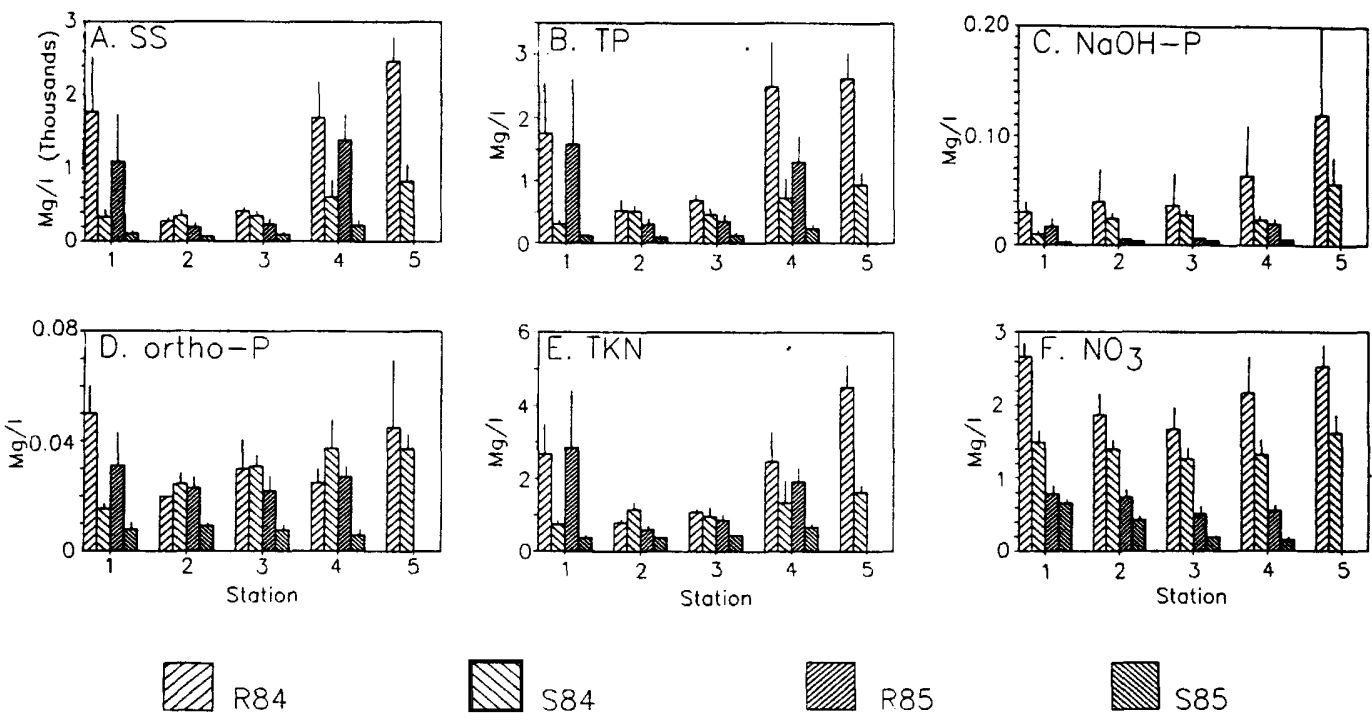

Fig. 1. Concentrations of (A) suspended solids, (B) total phosphorus, (C) sodium hydroxide-extractable phosphorus, (D) ortho-phosphorus, (E) total Kjeldahl nitrogen, and (F) nitrate-nitrogen in water samples taken at the five unpaired stations on Currant Creek. Station 1 is above the three complexes of beaver ponds, 2 and 3 are in the complexes, and 4 and 5 are below the complexes. Station 5 was not sampled during 1985. R84 and R85 denote the spring runoff periods of 1984 and 1985, respectively, and S84 and S85 denote the summer period of those years. Vertical lines represent standard errors of the estimate.

\section{Spring runoff}

For spring runoff in general during 1984, concentrations of suspended solids (SS), total phosphorus (TP), total Kjeldahl nitrogen (TKN), and nitrate nitrogen $\left(\mathrm{NO}_{3}-\mathrm{N}\right)$ were reduced in water flowing through the portion of stream containing beaver ponds. Concentrations then increased downstream from these areas (Fig. 1). Thus concentrations of these parameters at unpaired stations within and immediately downstream from the section with ponds (2 and 3) were significantly less than at upstream stations and several $\mathrm{km}$ downstream (1, 4, and 5). There were no significant differences in concentrations of $\mathrm{NaOH}$-extractable phosphorus ( $\mathrm{NaOH}-\mathrm{P})$, although concentrations appeared to increase downstream from the ponds (stations 4 and 5). There was no noticeable trend for concentrations of ortho-phosphate (ortho-P).

Generally, during spring runoff in 1985 concentrations of SS, TP, $\mathrm{NaOH}-\mathrm{P}$, ortho-P, and TKN were reduced in those portions of the creek containing beaver ponds. As in 1984, concentrations then increased downstream (Fig. 1). First considering unpaired stations, concentrations of SS, TP, and $\mathrm{NaOH}-\mathrm{P}$ were significantly less within and immediately downstream from sections with ponds (stations 2 and 3) than they were upstream and several $\mathrm{km}$ downstream (stations 1 and 4). A regression of $\mathrm{NO}_{3}-\mathrm{N}$ vs distance downstream indicated a significant decrease downstream, with most of the decrease occurring within the portion of stream containing beaver ponds. At the paired stations concentrations of SS, NaOH-P, TP, and TKN were reduced in water flowing through the ponds. This difference was statistically significant for SS and $\mathrm{NaOH}-\mathrm{P}$.

\section{Summer flow}

At unpaired stations during summer in 1984, concentrations did not decrease in portions of the creek containing beaver ponds as they did during spring runoff. Instead, concentrations of ortho-P, SS, TP, $\mathrm{TKN}$, and $\mathrm{NaOH}-\mathrm{P}$ increased generally in a downstream direction, and, except for TKN, all regressions of parameter concentration vs distance downstream were significant. The increase in concentration is most evident downstream from the beaver pond complexes (from stations 3 to 5) for all parameters except or tho-P. $\mathrm{NO}_{3}-\mathrm{N}$ displayed the same tendency in the summer as during runoff, but differences were not significant. At the paired stations, SS were significantly reduced in water flowing through the pond complexes. TP exhibited this same trend, but differences were not significant.

During early summer in 1985 at unpaired stations, regressions of TP and TKN vs distance again indicated significantly increased concentrations in a downstream direction. Most of the increase occurred downstream from the beaver pond complexes (from stations 3 to 4). The opposite occurred with $\mathrm{NO}_{3}-\mathrm{N}$; concentrations significantly decreased in a downstream direction, with most of the decrease occurring in the area of the beaver ponds. SS exhibited the same tendency as during runoff, but differences were not significant. No significant differences occurred for ortho-P or $\mathrm{NaOH}-\mathrm{P}$, although concentrations of $\mathrm{NaOH}-\mathrm{P}$ tended to increase downstream. At paired 


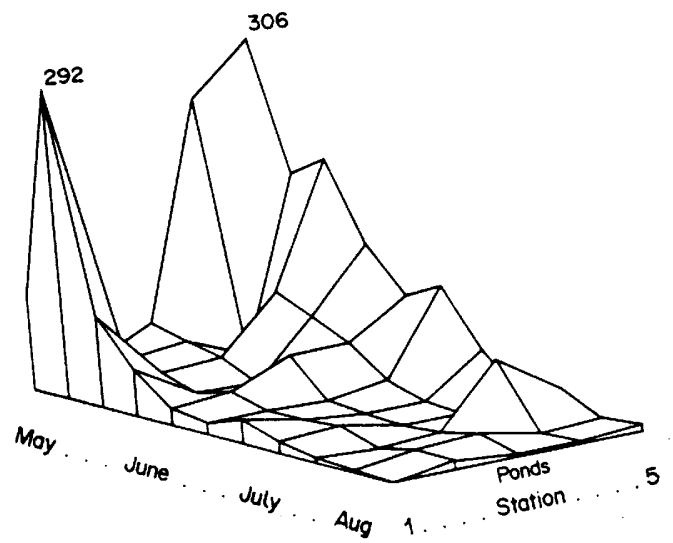

Fig. 2. Daily loads of suspended sediment (thousands of $\mathrm{kg} \mathrm{d}^{-1}$ ) calculated from values of concentration and discharge at the five unpaired stations during 1984. The abscissa represents the 11 sampling dates, the ordinate the five stations, and the height of the surface depicts daily loading with the two largest values labeled on the figure.

stations, concentrations of $\mathrm{NO}_{3}-\mathrm{N}, \mathrm{SS}$, and TP were reduced in water flowing through the pond complexes. This difference was statistically significant only for $\mathrm{NO}_{3}-\mathrm{N}$.

\section{Data from all analyses}

The variation of parameters as a function of both time and distance along the stream is difficult to visualize from Fig. 1. However, the impression gained from Fig. 2 (estimates of daily loading for SS) reasonably portrays such relationships for parameters significantly related to SS (e.g. TP, TKN).

During both years, concentrations of all chemical parameters decreased as the season progressed, as did discharge. Considering all data from both years, there was a significant, positive, $\log$-log relationship between discharge and the concentration of TP, TKN, ortho-P, $\mathrm{NaOH}-\mathrm{P}$ and $\mathrm{NO}_{3}-\mathrm{N}\left(r^{2}\right.$ ranged from 0.25 to 0.51 ). The values of $r^{2}$ always were larger during spring runoff than during summer.

Also during both years, significant positive normal-normal relationships existed between SS and concentrations of TP and TKN, and between ortho-P and TP (Table 1). In addition, the multiple regressions of $\mathrm{NaOH}-\mathrm{P}$ on (SS plus ortho-P) were significant $\left(r^{2}\right.$ ranged from 0.19 to 0.98$)$. In general, more variation in the dependent variables of all these regression analyses was explained (1) during runoff when concentrations of SS were highest, and (2) when the data were obtained using grab rather than composite samples.

Concentrations of ammonia almost always were at

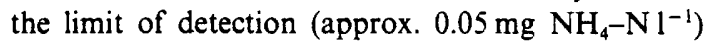
during both 1984 and 1985 . Thus no trend was observed for ammonia.

\section{Spring runoff}

\section{DISCUSSION}

Beaver ponds do affect water quality in Currant Creek. This effect is most pronounced during the high

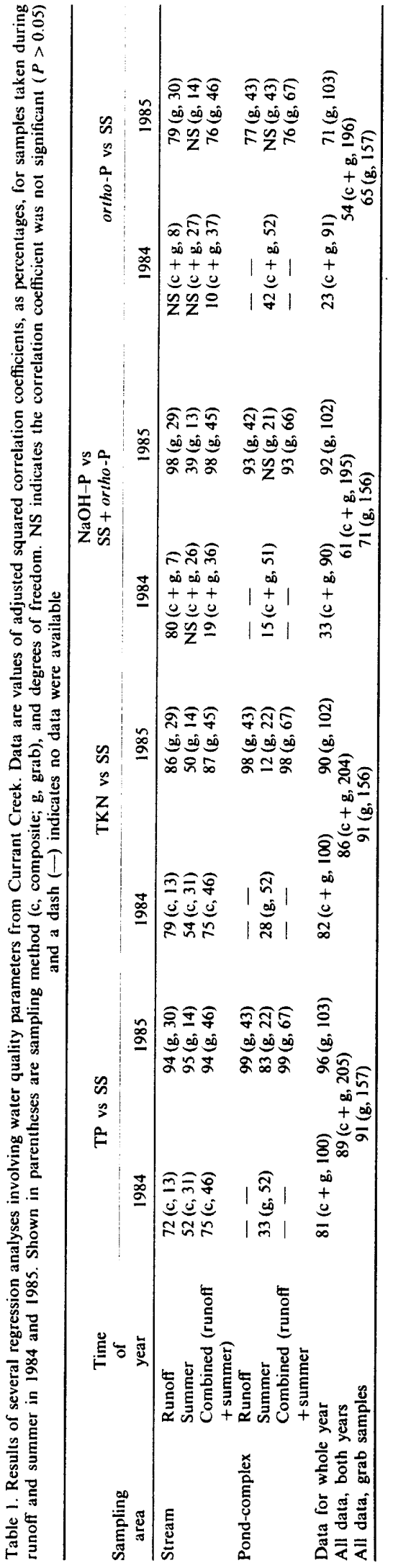


flows of spring runoff. During runoff in both years, concentrations of SS, TP, TKN and $\mathrm{NO}_{3}-\mathrm{N}$ were reduced in water flowing through the beaver ponds (Fig. 1). Concentrations then tended to increase downstream. In addition, during runoff in 1985 concentrations of $\mathrm{NaOH}-\mathrm{P}$ and ortho-P also were reduced in water flowing through the beaver ponds.

Trapping of particulates by the beaver ponds is a major mechanism causing the changes we observed, and erosion appears to be the source of particulates. The occurrence of such erosional input, especially during runoff, is supported by several lines of evidence. First, the power of water to erode is a function of velocity, which is related to discharge. Second, field observations showed turbid water present upstream or downstream from the ponds earlier in the year. Also, the stream channel becomes downcut in the area below the beaver pond complexes suggesting increased erosion. Third, the relation between concentration and discharge for most parameters is significant and positive. This suggests erosive input rather than dilution by snowmelt. Finally, the results of other studies indicate that bank and channel erosion can contribute greatly to sediment loads (e.g. Roseboom and Russell, 1985; Wilken and Hebel, 1982; Lowham et al., 1982).

$\mathrm{NO}_{3}-\mathrm{N}$ is soluble and does not adsorb readily to sediment particles. Therefore the decrease of $\mathrm{NO}_{3}-\mathrm{N}$ in ponds likely is caused by mechanisms different from those processes involving sediments. The primary factor probably is denitrification within the sediments of the ponds and associated wetlands (e.g. Brinson et al., 1981). Riparian vegetation, aquatic macrophytes, and benthic algae also may play a role in removing nitrate from the water (Lowrance et al., 1984; Duff et al., 1984).

The presence of fewer cattle in the study area during 1985 may help explain why beaver ponds had no effect on the high concentrations of $\mathrm{NaOH}-\mathrm{P}$ during runoff in 1984, but had a significant effect during runoff in 1985 when concentrations were lower (Fig. 1). The phosphorus measured as $\mathrm{NaOH}-\mathrm{P}$ can originate from both dissolved and particulate sources (Dorich et al., 1984). If cattle or their activity provided a large source of the dissolved fraction during 1984, and if the relative contribution from other sources was small, then variation in these other sources would not have been detected. But since cattle were practically absent in 1985 , relatively small changes in $\mathrm{NaOH}-\mathrm{P}$ owing to deposition of the particulate fraction within the beaver ponds would not be masked by a large input owing to cattle. The fact that concentrations of $\mathrm{NaOH}-\mathrm{P}$ generally were higher in 1984 than in 1985 supports this explanation.

\section{Summer flow}

During both summers, beaver ponds did not improve water quality to the same extent as during runoff. This most likely occurs because water entering the ponds during the period of low summer flow carries fewer and smaller particles, and therefore upon slowing down deposits a smaller percentage of its sediment load. Also, during high flows water is spread out over a large area, but during the lower summer flows it moves through channels and gradually erodes some of the previously deposited sediments. Despite this, results from the paired stations indicate that beaver ponds trap some sediment and associated phosphorus even during low summer flows.

\section{Data from all analyses}

We analyzed data from different years separately in part because there appeared to be differences attributable to sampling methods (composite or grab). This separation was particularly important for analyses involving parameters which were sampled by different methods (e.g. regression of ortho-P on SS, Table 1). In general, correlations between the dependent and independent variables of regressions always were less for analyses based on composite plus grab samples than for analyses based only on grab samples (e.g. Table 1, bottom two rows).

Concentrations of SS were significantly and highly correlated with a number of other parameters (e.g. TP, TKN, NaOH-P, ortho-P). Thus, in Currant Creek where erosion is such an important process, SS would be the best surrogate to use in relations explaining or predicting variation in these other parameters. For example, values of correlation coefficients from the regressions of ortho-P on SS or of $\mathrm{NaOH}-\mathrm{P}$ on (SS plus ortho-P) (Table 1) were virtually identical to values of coefficients from regressions using TP instead of SS.

We measured $\mathrm{NaOH}-\mathrm{P}$ because it has been suggested as an index of biologically available phosphorus (Dorich et al., 1984; Messer et al., 1984). The phosphorus measured by $\mathrm{NaOH}-\mathrm{P}$ can originate from both soluble (e.g. ortho-P) and particulate (e.g. SS) sources. Therefore, our regression analyses used both SS and ortho-P as independent variables. The regressions always explained more variance in $\mathrm{NaOH}-\mathrm{P}$ during runoff than during summer (Table 1). In addition, the standardized regression coefficients for SS always equalled or greatly exceeded those for ortho-P. Thus if NaOH-P is a good index of biologically available phosphorus, then, particularly during periods of high flow, in Currant Creek most such phosphorus appears to be associated with particulates. This conclusion again emphasizes the importance of erosive processes in Currant Creek and other similar watersheds.

Because beaver ponds trap sediments and associated nutrients, they also reduce export of these parameters downstream. By combining data on discharge with the chemical data, we estimated daily loads of SS, TP, TKN and $\mathrm{NO}_{3}-\mathrm{N}$ for the sampled period in 1984. Because the sampling period in 1985 only included runoff and a few weeks of summer flow, loads were not determined for 1985. During runoff in 
1984 the daily loads of SS for the sampled period were reduced in the area of the beaver ponds and increased again downstream (Fig. 2). The data for TP, TKN and $\mathrm{NO}_{3}-\mathrm{N}$ all exhibit this pattern.

\section{Management implications}

Our data illustrate the importance of location of beaver ponds along a stream in improving water quality. If water quality is to be maintained downstream from ponds and if nutrient export to a lake or reservoir is to be reduced, then the channel downstream from the pond complex must be stable or the pond complex must be located close to the lake or reservoir. If the channel below the pond complex is not stable, then developing dams close to the receiving water would decrease loading. It then becomes important to predict whether the dams have a high probability of persisting through time (Parker et al., 1985).

Important processes in riparian zones which affect movement of nutrients through watersheds have been described for agricultural areas (e.g. Lowrance et al., 1984). However in smaller downcut streams, typical of the arid west, two alternate mechanisms influenced by beaver dams markedly affect nutrient movement: (1) nutrient trapping, as described in this paper; and (2) erosive input of nutrients, which is minimized as beaver dams decrease the velocity of flow (Parker $e t$ al., 1985).

Thus when comparing downcut streams in the west to some streams in the agricultural east, the processes of most importance to movement of nutrients appear quite different. These differences should affect the choice and development of models, and the choice of mitigation schemes to maintain and improve water quality.

Acknowledgements - We thank Craig Thompson and Steve Greb who oversaw the chemical analyses at the Water Quality Laboratory, Western Wyoming College, Rock Springs, Wyo. Bruce H. Smith, Larry L. Apple, Chris Butler and Fred D. Stabler provided helpful guidance and discussion. The U.S. Environmental Protection Agency and the U.S. Bureau of Land Management loaned the automatic water samplers. Access to the study area was graciously granted by the owners of the Currant Creek Ranch. The research was supported in part through the Wyoming Water Research Center.

\section{REFERENCES}

APHA (1980) Standard Methods for the Examination of Water and Wastewater, 15th edition. American Public Health Association, Washington, D.C.

Apple L. L. (1985) Riparian habitat restoration and beavers. In Riparian Ecosystems and their Management: Reconciling Conflicting Uses (Edited by Johnson R. R., Ziebell C. D., Patton D. R., Ffolliott P. F. and Hamre R. H.), pp. 35-38. First North American Riparian Conference; April 16-18; Tucson, Ariz. Gen. Tech. Rep. RM-120 USDA, Forest Serv., Rocky Mt. Forest and Range Expt. Station. Ft. Collins, Colo.

Brinson M. M., Bradshaw H. D. and Kane E. S. (1981) Nitrogen cycling and assimilative capacity of nitrogen and phosphorus by riverine wetland forests. Water $\mathrm{Re}$ sources Research Institute of the University of North Carolina Report Number 167.
Dorich R. A., Nelson D. W. and Sommers L. E. (1984) Algal availability of phosphorus in suspended stream sediments of varying particle size. J. envir. Qual. 13, 82-86.

Duff J. H., Triska F. J. and Oremland R. S. (1984) Denitrification associated with stream periphyton: chamber estimates from undisrupted communities. J. envir. Qual. 13, 514-518.

Francis M. M., Naiman R. J. and Melillo J. M. (1985) Nitrogen fixation in beaver (Castor canadensis) influenced subarctic streams. Hydrobiologia 121, 193-202.

Jacobs T. C. and Gilliam J. W. (1983) Nitrate loss from agricultural drainage waters: implications for nonpoint source control. Water Resources Research Institute of the University of North Carolina Report Number 209.

Lowham H. W., De Long L. L., Collier K. R. and Zimmerman E. A. (1982) Hydrology of Salt Wells Creek-a plains stream in southwestern Wyoming. U.S. Geological Survey Water-Resources Investigations 81-62.

Lowrance R., Todd R., Fail J. Jr, Hendrickson O. Jr, Leonard R. and Asmussen L. (1984) Riparian forests as nutrient filters in agricultural watersheds. Bioscience 34, 374-377.

Messer J. J., Ihnat J. M. and Wegner D. L. (1984) Phosphorus release from the sediments of Flaming Gorge Reservoir, Wyoming, U.S.A. Verh. int. Verein Limnol. 22, 1457-1464.

Munther G. L. (1982) Beaver management in grazed riparian ecosystems. In Proceedings of the Wildlife-Livestock Relations Symposium: Proceedings 10 (Edited by Peek J. M. and Dalke P. D.), pp. 234-241. University of Idaho, Forest, Wildlife, and Range Experiment Station, Moscow, Idaho.

Naiman R. J. and Melillo J. M. (1984) Nitrogen budget of a subarctic stream altered by beaver (Castor canadensis). Oecologia 62, 150-155.

Parker M., Wood F. J. Jr, Smith B. H. and Elder R. G. (1985) Erosional downcutting in lower order riparian ecosystems: have historical changes been caused by removal of beaver? In Riparian Ecosystems and their Management: Reconciling Conflicting Uses. (Edited by Johnson R. R., Ziebell C. D., Patton D. R., Ffolliott P. F. and Hamre R. H.), pp. 35-38. First North American Riparian Conference; April 16-18; Tucson, Ariz. Gen. Tech. Rep. RM-120. USDA, Forest Serv., Rocky Mt. Forest and Range Expt. Station. Ft. Collins, Colo.

Platts W. S., Megahan W. F. and Minshall G. W. (1983) Methods for Evaluating Stream, Riparian, and Biotic Communities. USDA Forest Service Intermountain Forest and Range Experiment Station. Ogden, Utah.

Roseboom D. and Russell K. (1985) Riparian vegetation reduces stream bank and row crop flood damages. In Riparian Ecosystems and their Management: Reconciling Conflicting Uses (Edited by Johnson R. R., Ziebell C. D., Patton D. R., Ffolliott P. F. and Hamre R. H.), pp. 241-244. First North American Riparian Conference; April 16-18; Tucson, Ariz. Gen. Tech. Rep. RM-120. USDA, Forest Serv., Rocky Mt. Forest and Range Expt. Station. Ft. Collins, Colo.

Smith B. H. (1980) Not all beaver are bad; or, an ecosystem approach to stream habitat management, with possible software applications. In Proceedings 15th Annual Meeting of Colorado-Wyoming Chapter of American Fisheries Society (Edited by Whaley R.), pp. 32-37.

Southwestern Wyoming Water Quality Planning Association (1978) Clean water report for southwestern Wyoming. CH2M-Hill Inc., Denver, Colo.

Systat Inc. (1984) Systat: The System for Statistics. Systat Inc., Evanston, IIl

U.S. EPA (1983) Methods for Chemical Analyses of Water and Wastes. EPA 600/4-79-020.

Wilken D. C. and Hebel S. J. (1982) Erosion, redeposition and delivery of sediment to midwestern streams. Wat. Resour. Res. 18, 1278-1282. 